very title shows how "History of English literature" is a phrase that has to be somewhat modified to isolate the literary product offered. This is achieved by means of the publishers' trademark that acts as a guarantee. Moreover, the title is qualified to avoid colonial or anglocentric connotations and the full message of both title and subtitle is that of a reliable, up-to-date, prejudices-free, literary history. The content of this carefully designed book fully strengthens the message included in its emblematic title and matches the prestige of the publisher, as it offers value for money.

Another outstanding feature of this volume is that it is a history of literature in which not only history but also literature is present. This is achieved by means of abundant quotations throughout the text and placed even as well-selected paragraph titles which give the text a literary flavour absent in many other literary histories. The work has a special emphasis on modern and contemporary literature since these are the most widely studied periods of English literature. As it may be seen from the mere space given to the different periods, the twentieth century requires approximately two hundred pages whereas old, middle, and renaissance literature cover little more than a hundred. Obviously, this is due to the quantity of texts preserved from ancient periods, to the importance of the printing press, and to the increase of the reading public that built a whole literary industry in the present century. However, although this is not not necessarily criticizable, one cannot avoid the feeling that the authors have a special interest for modern literature to the detriment of other periods. This may be due to the lack of perspective that we all have about the literary products of our age as they have not yet been filtered through time.

As a whole we can say that we have before us a carefully written work that has all the essential features (including index, Timelines by Jeremy Hunter, and Nobel Prize Winners list) to become a widely considered reference and text book in both schools and universities, useful for students and scholars of English literature throughout the world. It is crystal clear, easy to read and, at the same time, scholarly and accurate in that it faithfully represents the panorama of the literary production of a linguistic community throughout the centuries.

María Jesús Lorenzo Modia

\title{
Margaret Atwood. Strange Things: The Malevolent North in Canadian Literature. Oxford: Clarendon, 1995, $126 \mathrm{pp}$.
}

This book consists of four lectures delivered by Margaret Atwood at Oxford University in the spring of 1991. In the Introduction Atwood makes it clear that she focuses on the mystique of the Canadian North and its influence on Canadian Literature as a whole, and that she speaks from her position as a non-scholar. To illustrate this, Atwood points out how she tried to match her earrings to the subject matter of each of her lectures; something, she claims, that a respectable academic would not have done.

The first lecture opens up with the problems involved in the definition of the Canadian identity. Atwood states that "the search for the fabled Canadian identity is like a dog chasing its own tail" (8) and this statement shows how the situation has changed since she published Survival in 1972. In the seventies Atwood wrote a book to put Canada in the 
literary world map, but now this is unnecessary because "there is the tail, as firmly attached to the dog as ever" (8). In Strange Things Atwood brings to light a collection of hackneyed images and stories, usually associated with the Canadian North, which exert a powerful fascination on Canadian writers so as to rework these motifs in their poems and novels, all of them written in English. Her first lecture thus focuses on one particular recurring motif: the failure of the Franklin expedition when they tried to discover the North-west Passage. As Franklin was never found, according to Atwood "he continues to live on as a haunting presence; certainly in Canadian literature" (16). Indeed, the author gives examples of literary works where the Franklin expedition is somehow present, but underpinning all those works is the concept of the North as an uncanny, hostile although alluring, environment. For example, E. J. Pratt felt so attracted to the Franklin story that he attempted to write it more than once, but he eventually wrote an epic on the sinking of the Titanic, another maritime disaster. Atwood's contention is that Pratt introduces some of the Franklin expedition story's elements as well as her own conception of the North as a powerful influence into his Titanic poem. Therefore, the first literary treatment that Atwood finds of this topic is Gwendoline MacEwen's verse drama Terror and Erebus (1963). After a period in which the Franklin story's mythic quality is undermined by several literary works, Graeme Gibson's 1982 novel Perpetual Motion takes up the serious quality of the motif again. In order to finish her first lecture, Atwood mentions other writers who have dealt with Franklin and his expedition, namely Mordecai Richler, and Rudy Wiebe. The song "The Northwest Passage" (1981), written by the Canadian singer Stan Rogers, also makes specific reference to northern explorators, including Franklin.

The second chapter is titled "The Grey Owl Syndrome" after the Englishman who in the nineteenth century emigrated to Canada, lived with the Indians, and once adopted by them, became a well-known writer and lecturer. "The Grey Owl Syndrome" refers to a good many non-Natives who want to turn themselves into Natives, and who see the wilderness as having enhancing power and renewing life. Two nineteenth-century writers were precursors of Grey Owl: John Richardson, who wrote Wacousta in 1832, and Ernest Thompson Seton. Thompson Seton's life and work provided the idea that one had to live like the Indians in the wilderness to survive the advancing decadence of white civilization. His 1912 Book of Woodcraft encapsulated the most positive values and attitudes towards the Indians ever seen. Here Atwood concentrates on Seton's long-lasting influence as well as on the way he developed a Woodcraft Indian Movement along democratic lines to be later "stolen from him by Baden-Powell and converted into the Boy-Scouts" (46). But it is Grey Owl who continues living in the literary pieces of some writers, and among them is Robert Kroetsch's 1973 novel Gone Indian. Atwood finally recognizes that the wish to go Indian is quite embedded in the Canadian culture, something she congratulates on, since in her opinion white society should learn from the Native attitude towards nature to stop environmental damages.

The third chapter deals with the myth of the dreaded snow monster, the multi-faceted Wendigo, an incarnation of going crazy in the North, and with the ways in which this myth has become a motif in Canadian literature. Atwood gives a rather useful introduction to this myth to an English audience, probably not acquainted with the Wendigo stories and tales. It is interesting to note the differences Atwood establishes between the Wendigo, 
confined to the eastern woodlands, and other man-eaters. When the Wendigo is mentioned by non-Natives in short and lyric poems, it stands for an object of meditation-humans themselves are potential monsters. But in longer pieces of literature Wendigoes tend to play the same role as ghosts in the ghost story or Gothic tale. In this sense, Atwood distinguishes three different ways of presenting the monster in relation to human characters: in the first kind of story, Wendigoes can be considered spirits of places. In the second kind, the creature is somewhat connected with the human character so that if that character gets eaten, it will be his/her fault i.e. William Henry Drummond's narrative poem "The Windigo" (1901). The third type of story has to do with the concept of being driven mad in Canadian North, which also receives the name of "getting bushed" or "cabin fever". In this specific case the supernatural creature represents a split-off element of the protagonist's psyche, developing a life of its own; here the concepts of getting "bushed" and "going Wendigo" overlap as in Wayland Drew's complex 1973 novel The Wabeno Feast.

The title of the fourth lecture is "Linoleum Caves", a quotation from Alice Munro's Lives of Girls and Women (1971). What strikes Atwood here is the combination of domesticity and wilderness, which leads her to bring the topic of the lecture in: the connections between the Canadian North and women as either authors or fictional characters. Despite the undoubtable presence of Canadian women writers, Atwood points out that there are neither myths concerning women and exploration nor many stories about women who wanted to become Indians like Grey Owl. However, some women have incorporated Indian motifs to their own works, namely, Susan Musgrave and Sheila Watson. The nearest thing to Grey Owl is E. Pauline Johnson, who succeeded as a performance artist and a poet in the last decades of the nineteenth-century. As there were some women who ended up in the woods, Atwood tries to establish a distinction between what she calls "the first wave", women of the nineteenth century who went to the woods because circumstances led them there, and "the second wave", those women of the twentieth century who following these first women write about them. In this sense, Anna Jameson and the sisters Susanna Moodie and Catharine Parr Traill offer three different viewpoints of the relation between women and the wilderness. The sisters' visions of a settler's life differ considerably, so whereas Traill's book is a practical book designed for prospective settlers, Moodie's Roughing It In the Bush is a warning to immigrants, emphasizing hardship and danger. Then, around the middle of the twentieth century, Canadian female protagonists start going off into the woods to be by themselves i.e. Maggie Vardoe in Ethel Wilson's 1954 novel Swamp Angel. More important, Marian Engel takes her heroine beyond humanity and close to Nature in her 1976 novel Bear, where she actually falls in love with a bear. The protagonist's quest to an island in Northern Ontario ends up when she finds in that creature the source for her spiritual renewal, achieving, in Atwood's words, "an authentic, strong self" (109). Margaret Atwood herself wrote her own woman-in-the-woods-novel back in 1972, Surfacing; insofar as both novels are female psychic quests, I think that at this point some commentary on her novel in relation to Engel's Bear could have brought some light to the subject. Regarding the Wendigo legend, Atwood finds the first female incarnation of this myth in Ann Tracy's 1990 novel Winter Hunger. 
Margaret Atwood finally links her own work to some of the imagery and Native lore she has been discussing, which gives a sort of circular structure to the book. What one misses here perhaps is a much more detailed analysis of her own writing, inextricably linked to the imagery of the Canadian North, a Canadian North which could cease to exist because of pollution and environmental carnage. She thus finishes her fourth lecture, and this book, by drawing the listener's, and the reader's, attention to environmental problems in Canada. Strange Things offers a fascinating portrait of the Canadian North, and an insight into the Canadian literary imagination. Both informative and exciting, it provides a very illuminating understanding of the mysterious North and of its lore, which has always allured poets and novelists alike. Atwood's Strange Things constitutes then a useful book to those who want to focus on the relationship between the Canadian North and story-telling, as well as a valuable piece of literature in itself.

Rosario Arias

Charles Bernheimer (ed.), Comparative Literature in the Age of Multiculturalism, Baltimore \& Londres, The John Hopkins University Press ("Parallax; Re-visions of Culture and Society"), 1995, 207 pp.

The volume that we are commenting is composed of three parts. If we do not take into account Bernheimer's preliminary chapter on "The Anxieties of Comparison", the first part gathers "Three Reports to the American Comparative Literature Association", elaborated by the commissions that presided professors Harry Levin in 1965, Thomas Greene in 1975 and Charles Bernheimer in 1993. These are the successive reports that have oriented their guidelines in the exercise of the comparative literature as an accademic discipline in American Universities. In the second part come together "Three Responses to the Bernheimer Report at the Modern Language Association Convention, 1993". The book is completed with a section of "Position Papers", in which appear thirteen articles prepared after the debate provoked by the Bernheimer Report, in 1993.

The paper entitled "Comparative Literature at the Turn of the Century" is the central one in this volume, for it contains many recommendations to renove the comparative research and to shape the new universitary Programs of Comparative Literature at Graduate and Undergraduate levels. Berheimer's Report, trying to sum up hte mos relevant contents of 1965 and 1975 previous Reports, draws a living picture of the major vicissitudes and mutations that comparative studies have experienced in the last thirty years. The editor of those Reports pointed out the growth of the discipline after World War II, based in the adoption of broader perspectives, but after all, it "did not often reach beyond Europe's high-cultural lineage going back to the civilizations of classical antiquity" (p. 40). That situation lead "to reinforce an identification of nation-states as imagined communities with national languages as their natural bases" (p. 40). In spite of warning about the dangers that threatened the comparativism of those days, inspired by traditional and immobilized conceptions, Levin and Green complained against the attempts of mining "the very basis of comparative literature's elite image" (p.40) of those who, by reasons of comfort, adopted translations instead of commenting the texts in their 